\title{
ETNOLOGIA NIEOCZYWISTA. \\ ŚLADAMI JANA STANISŁAWA BYSTRONIA STO LAT PÓŹNIEJ
}

\section{WPROWADZENIE}

Utarło się powiedzenie, że klasyków uwielbiamy, ale rzadko ich czytamy. Wydaje się jednak, że w przypadku Jana Stanisława Bystronia sytuacja wygląda inaczej. Jego olbrzymi dorobek naukowy inspirował kolejne pokolenia antropologów, a upływ czasu pozwala dostrzec na nowo problemy, które w swoich artykułach i książkach opisywał już w początkach minionego stulecia. Przywołajmy tylko kilka przykładów takich inspiracji.

Wydany w 1980 roku przez Ludwika Stommę zbiór niewznawianych od międzywojnia prac Jana Stanisława Bystronia Tematy, które mi odradzano (Bystroń 1980) wyraźnie zwiastował wzrost zainteresowania jego twórczością. Wybór dokonany przez Stommę zawierał kilkanaście mniejszych objętościowo prac Bystronia, które pokazywały nie tylko jego szerokie horyzonty badawcze, ale również aktualność sądów i nowatorskość myśli. Jak wskazywali recenzenci tomu, „tajemnica” renesansu Bystronia tkwiła $\mathrm{w}$ umiejętności błyskotliwego poruszania się pomiędzy różnymi problemami i zagadnieniami społecznymi, a także swobodnego łączenia ze sobą różnych teorii czy perspektyw analitycznych. Otwarty model nauki mógł eksplodować odkryciami badawczymi i pomysłami, których spora część zasługiwała na kontynuację i rozwinięcie (Waliński 1982, s. 140).

$\mathrm{Z}$ takiego wzorca wyrastała bezpośrednio antropologia Czesława Robotyckiego. Był on w takim samym stopniu jak Bystoń etnografem czułym na obyczajowe szczegóły i potrafiącym osadzić je w kulturowo-historycznych kontekstach. Robotycki w książce Nie wszystko jest oczywiste (1998) na pozór błahym zjawiskom przypisywał głębszy, społeczny wymiar. Analogicznie jak Bystroń związany był z krakowskim i poznańskim środowiskiem etnologicznym.

Antropologia ustrukturyzowana w codziennych praktykach stała się także punktem zwrotnym w badaniach Rocha Sulimy. Jego książka Antropologia codzienności (2000), opisująca kulturowe „oczywistości” od mikroświatów ogrodów działkowych po imiona widywane na murach i retorykę konsumpcji, w swojej zasadniczej formule odnosiła się do bystroniowskiej optyki. Jak napisał Sulima, „Antropologia codzienności [...], którą przynosi ta książka, ma na polskim gruncie wielu poprzedników. 
Wymienię tu w najprostszej linii m.in. prace Jana Stanisława Bystronia zebrane i skomentowane przez Ludwika Stommę" (2000, s. 192). Fascynacje peryferiami kulturowymi oraz tym, co określić można „małymi podbojami”, wpisane zostały w etnologiczny obieg doktryn i metod badawczych.

Interdyscyplinarne podejście Bystronia do kwestii kulturowych sprawiło, że zapisał się on nie tylko w historii etnologii polskiej, ale także socjologii, folklorystyki, pedagogiki, lingwistyki. Przede wszystkim z tego powodu Joanna Tokarska-Bakir i Anna Zawadzka powołały niedawno do życia międzydyscyplinarne pismo, które wprost nawiązuje do idei naukowych Jana Stanisława Bystronia. Komunikacja pomiędzy poszczególnymi dziedzinami nauki, zwłaszcza etnografią, socjologią, literaturoznawstwem i filozofią z jednej, a historią z drugiej strony, oraz ukazywanie powiązań między teorią a praktyką jest tym, co w bystroniowskim podejściu do humanistyki pozostaje wciąż aktualne. Tokarska-Bakir i Zawadzka przyznają, że prace Bystronia cieszą się niesłabnącą popularnością wśród kolejnych pokoleń badaczy, stając się niekwestionowanym etnograficznym evergreenem (Tokarska-Bakir, Zawadzka 2012, s. 1-2).

Aktywna działalność naukowa Jana Stanisława Bystronia, urodzonego w 1892 roku w Krakowie, przypadła na okres instytucjonalnego formowania się etnologii jako samodzielnej dyscypliny naukowej zaraz po zakończeniu I wojny światowej i odzyskaniu przez Polskę niepodległości. Chodzi o rozwój katedr na uniwersytetach polskich, a także czynny wpływ na kształtowanie procesu dydaktycznego w ramach akademickich studiów etnologicznych. W tym czasie prowadzono ożywione dyskusje nad koncepcjami umiejscowienia etnologii na tle innych nauk oraz refleksję nad głównymi zadaniami dyscypliny. Jego biografia naukowa pozostaje ważną częścią historii etnologii i humanistyki polskiej. Studia filologiczne i doktorat $\mathrm{z}$ filozofii na podstawie rozprawy Teoria rzeczywistości społecznej (1914) na Uniwersytecie Jagiellońskim, pobyt w École des Hautes Études w Paryżu (1912-1913), habilitacja z zakresu etnologii (1918) na podstawie publikacji Zwyczaje żniwiarskie w Polsce (1916) i wreszcie objęcie Katedry Etnologii i Folklorystyki w nowo utworzonym Uniwersytecie Poznańskim (1919-1925), pierwotnie nazywanym Wszechnicą Piastowską, pokazują dynamiczny początek kariery naukowej Bystronia. Miała ona kilka znaczących zwrotów. Po pięciu latach profesury w Poznaniu Bystroń został kierownikiem Katedry Etnologii Uniwersytetu Jagiellońskiego (1925-1934). Następnie przeniósł się do Warszawy, gdzie kierował Katedrą Socjologii Uniwersytetu Warszawskiego (1934-1948). Piastował również stanowisko dyrektora Departamentu Szkół Wyższych w Ministerstwie Wyznań Religijnych i Oświecenia Publicznego (1934-1936). W okresie międzywojennym opublikował kilkadziesiąt prac o różnej tematyce: od zagadnień poświęconych tradycyjnej kulturze ludowej po nowatorską antropologię komizmu. Kataklizm II wojny światowej, śmierć syna Andrzeja (1943), a następnie żony Jadwigi (1948) znacząco wpłynęły na jego aktywność zawodową. Pod koniec życia Bystroń, dotknięty chorobą, „wegetował cicho i smutnie przy zupełnej bezsile lekarskiej wiedzy" (Bielak 1979, s. 286). Kiedy zmarł w 1964 roku, żegnała go na warszawskim cmentarzu gromadka znajomych i przyjaciół. Jak napisali Kazimierz Dobrowolski i Anna Kutrzeba-Pojnarowa we wspomnieniach, Bystroń podzielił los 
„niejednego z wybitnych uczonych, których spaliła pasja poznawcza, bezgraniczne oddanie nauce" (Dobrowolski, Kutrzeba-Pojnarowa 1966, s. 27).

Janowi Stanisławowi Bystroniowi poświęcono kilka opracowań biograficznych (np. Bielak 1965; 1979; Sierakowski 2008), niektóre zaś jego dzieła wydawano kilkukrotnie. To świadczy bez wątpienia o jego znaczącym wkładzie w polską etnologię i inne nauki społeczne. Niniejszy artykuł nie jest próbą holistycznego spojrzenia na całokształt dorobku Bystronia, co byłoby zamierzeniem trudnym i skomplikowanym do realizacji. Ograniczam się jedynie do okresu, kiedy tworzył Katedrę Etnologii funkcjonującą w ramach struktury Uniwersytetu Poznańskiego i pracował tam. Jego działalność na rzecz tej placówki uniwersyteckiej można uznać za swoisty „początek” nie tylko kariery profesorskiej i naukowej rozpatrywanej w kategoriach osobistych. To także czas powołania najstarszego ośrodka etnologicznego w Polsce, dziś noszącego nazwę Instytut Etnologii i Antropologii Kulturowej Uniwersytetu im. Adama Mickiewicza w Poznaniu, którego historia rozpoczyna się wraz z otrzymaniem w 1919 roku przez Bystronia aktu nominacji kierowania Katedrą Etnologii. Pobyt w Poznaniu, choć niezwykle krótki, był dla młodego profesora etnologii istotny z kilku powodów. Po raz pierwszy mógł wykazać się umiejętnościami kierowania katedrą, które później rozwijał w Krakowie i Warszawie. Praca w nowo otwartym Uniwersytecie Poznańskim sprzyjała i motywowała do prowadzenia intensywnych badań naukowych oraz realizacji planów wydawniczych. Bystroń, będąc kierownikiem poznańskiej etnologii, opublikował kilka monografii, artykułów i recenzji, pokazujących charakterystyczne sposoby myślenia o kulturze, którą analizował, i oczywiście samej etnologii, którą uprawiał. Był to rzeczywisty początek formułowania wielu pomysłów badawczych, które ewoluowały w późniejszych jego publikacjach, gdy nie był już związany z Uniwersytetem Poznańskim. Należą do nich choćby studia z zakresu megalomanii narodowej, antropologii miasta i kultury codzienności.

Artykuł nie tylko ogranicza się do konkretnego przedziału czasowego, ale skupia się również na dwóch zasadniczych obszarach: instytucjonalnym (bystroniowska wizja etnologii jako nauki akademickiej) oraz problematyce tak zwanego dziedzictwa kulturowego (bystroniowskie ujęcie zagadnień i problemów kulturowych). Ta podwójna perspektywa pozwala spojrzeć szerzej na działalność naukową Bystronia, która uformowała zręby Katedry Etnologii w Poznaniu. Przy pisaniu tego tekstu korzystałem z archiwum Uniwersytetu im. Adama Mickiewicza, w którym znajdują się pisma i dokumenty związane z Bystroniem z czasów, kiedy pracował w Katedrze Etnologii Uniwersytetu Poznańskiego (Sygn. AUAM 152.4, Akta profesury, s. 1-62). Sięgnąłem również do spisów wykładów prowadzonych na Uniwersytecie Poznańskim w okresie międzywojennym. Ponadto odwołuję się do konkretnych prac Bystronia, które ukazały się przede wszystkim w latach 1919-1925 i późniejszych, stanowiących kontynuację studiów kulturowych zapoczątkowanych w Poznaniu. Są to zarówno książki, jak i kilkustronicowe artykuły zamieszczone w czasopismach naukowych i popularnonaukowych.

W tym miejscu pragnę podzielić się jeszcze jedną refleksją. Prezentowany artykuł jest w zasadniczym stopniu rezultatem analizy tekstów i archiwaliów, które pozostawił 
po sobie Bystroń w czasie, gdy kierował Katedrą Etnologii Uniwersytetu Poznańskiego. Pewne problemy sprawiła sama konceptualizacja i uporządkowanie tych źródeł. Trudno bowiem znaleźć u Bystronia dominujący paradygmat badawczy, a źródła archiwalne stanowią bardzo rozproszony zestaw świadectw o działalności jego i katedry, którą mu powierzono. Dlatego w tekście staram się jedynie zarysować kierunki refleksji nad szeroko rozumianą kulturą, a także spojrzeć przez pryzmat skąpych materiałów archiwalnych na wysiłek budowania poznańskiej placówki etnologicznej. Jan Stanisław Bystroń nigdy nie prowadził badań terenowych, a swoją wiedzę czerpał „z drugiej ręki”. Pisał książki i artykuły na podstawie własnych analiz literatury, pamiętników, wspomnień, kronik, kazań, protokołów parafialnych itp. (por. m.in. Mancewicz 2001). Styl jego prac był raczej patchworkowy, a rozpoznanie różnych konwencji stało się dla mnie ćwiczeniem teoretycznej otwartości i treningiem uważności. Dzięki temu antropologię Bystronia potraktowałem także jako intelektualny „bagaż” pomocny przy przekraczaniu barier dyscyplinarnych i granic historycznych. Choć w niewielkim stopniu bystroniowską etnologię minionego wieku starałem się odnieść do współczesnych realiów w myśl zasady, o której wspomniał kiedyś James Clifford, że temporalny rozwój etnografii jako nauki wymaga dostosowania do teraźniejszych dyskusji polityczno-epistemologicznych (Clifford 2000, s. 32). Można dodać, że takie podejście naukowe łączy refleksyjność „nad sobą” i „przedmiotem” $\mathrm{z}$ aspektami heterogeniczności i hybrydalności. Pozostaje unikalną formą stawiania pytań badawczych i wyboru problemów (Davies 1999, s. 8). Tę podwójną perspektywę zauważamy również w pracach Bystronia, których historyczność nie przysłania złożoności tego, co określamy mianem współczesności. W jego argumentacji pojawiają się problemy, które obecnie powróciły w nieco zmienionej perspektywie, wskazując choćby na strach przed wielokulturowością czy granice społecznej tolerancji. Toteż etnologia - ta dzisiejsza i bystroniowska - pozostaje nauką nieoczywistą, łączącą różne konteksty i perspektywy, a jej zasoby zarówno intelektualne, jak i instytucjonalne mogą być zawsze ujmowane w zmiennych relacjach.

\section{KATEDRA, DYDAKTYKA I NAUKA}

Początki historii poznańskiej etnologii nierozerwalnie wiążą się z osobą profesora Jana Stanisława Bystronia. To właśnie jemu 22 listopada 1918 roku z polecenia Komitetu wyłonionego z Towarzystwa Przyjaciół Nauk w Poznaniu, zajmującego się organizacją Wszechnicy Piastowskiej, formalnie przemianowanej 10 kwietnia 1920 roku na Uniwersytet Poznański, zaproponowano objęcie Katedry Etnologii. Mieszkający wówczas w Krakowie Bystroń zgodził się tę propozycję. Ostatecznie 22 lutego 1919 roku na wniosek Komisariatu Naczelnej Rady Ludowej w Poznaniu oraz w wyniku uchwały powziętej przez Międzyuniwersytecką Komisję Stabilizacyjną w Krakowie przekazano Bystroniowi kierowanie poznańską etnologią. Początkowo Katedra Etnologii nazywana była Katedrą Etnologii i Folklorystyki, a towarzyszył jej Instytut Etnologiczny, umożliwiający tworzenie struktury dydaktycznej i badawczej. 
W pierwszych latach funkcjonowania Instytutu Etnologicznego jego asystentką była Bożena Stelmachowska. Katedra wchodziła w skład ówczesnego Wydziału Filozoficznego, którego pierwsze posiedzenie odbyło się 4 kwietnia 1919 roku' ${ }^{1}$.

W momencie powierzenia Bystroniowi Katedry Etnologii miał on skończone dopiero 26 lat. Trzeba pamiętać, że u progu II Rzeczypospolitej tworzenie się uniwersytetów było szansą dla ludzi młodych. Wśród kadry akademickiej nie tylko w Poznaniu dominowali trzydziestolatkowie, a okres ten bywa nazywany „ofensywą młodych” (Schramm 2002, s. 140). Z całą pewnością Bystroń był częścią owej ofensywy młodych uczonych, szukających swojego miejsca na nowo otwieranych polskich uczelniach. Co ciekawe, należał on do grona najmłodszych profesorów uniwersyteckich mianowanych na kierowników katedr. W całym okresie międzywojennym na Uniwersytecie Poznańskim tylko pięć osób poniżej 30. roku życia otrzymało takie nominacje. Dla przykładu oprócz Bystronia profesorami nadzwyczajnymi kierującymi katedrami byli Tadeusz Lehr-Spławiński (27 lat), pracujący w Katedrze Filologii Słowiańskiej, i niewiele starszy Tadeusz Pęczalski (29 lat), kierownik Katedry i Zakładu Fizyki Teoretycznej (Jakś-Ivanovska 2016, s. 347).

Już jesienią 1919 roku Bystroń rozpoczął wykłady uniwersyteckie w Poznaniu. Zajęcia $\mathrm{z}$ etnologii koncentrowały się na czterech obszarach: (1) etnograficznych analizach pieśni ludowych i literaturze ludowej - Polska pieśń ludowa $(1919,1920)$, Czytanie i rozbiór polskich pieśni ludowych $z$ uwzględnieniem ich wpływu na poezje literacka (1919), Polska pieśń ludowa (czytanie i objaśnianie wybranych pieśni ze szczególnym uwzględnieniem wplywu ich na poezję literacka) (1920), Studja źródłowe nad literatura ludowa (pieśni i podania) (1922), Polskie przystowia i zagadki ludowe (1922), Polska literatura ludowa (1925), Wędrówki wątków literackich (1925), (2) ludoznawstwie / etnografii polskiej - Wstęp do ludoznawstwa polskiego (1924, 1925), Krótki zarys ludoznawstwa polskiego (1925), Konwersatorium ludoznawcze (1925), Kultura umysłowa ludu polskiego (1925), Wybrane rozdziały z etnografji polskiej (1919), Etnografja Polski (1923, 1924), (3) studiach etnicznych - Psychologja etniczna (1921, 1924), Wybrane zagadnienia $z$ psychologji etnicznej (1921, 1922), (4) metodologii i socjologii kultury - Socjologia (1920), Socjologia ziem polskich (1925), Metody badań etnograficznych (1925).

Jego zainteresowania dydaktyczne ściśle korespondowały z dorobkiem naukowym, do którego odnoszę się szerzej w dalszej części artykułu. Oprócz wyżej wymienionych wykładów i konwersatoriów, Bystroń od 1919 roku do 1925 roku prowadził seminaria i proseminaria etnologiczne, wykładał także socjologię dla studentów studiów ekonomicznych na Wydziale Prawnym, na co zgodził się dziekan Wydziału Filozoficznego. Warto w tym miejscu wspomnieć, że w 1920 roku została przygotowana praca

${ }^{1}$ Uczestnikami pierwszej Rady Wydziału obok Jana Stanisława Bystronia byli Alfred Denizot (fizyk), Ryszard Ganszyniec (filozof), Jan Grochmalicki (zoolog), Seweryn Hammer (filozof), Antoni Korczyński (chemik), Józef Kostrzewski (archeolog), Tadeusz Lehr-Spławiński (slawista), Kazimierz Tymieniecki (historyk), Eugeniusz Piasecki (teoretyk wychowania fizycznego), Mikołaj Rudnicki (językoznawca), Franciszek Włodarski (matematyk) i Heliodor Święcicki (lekarz), wybrany 5 kwietnia jednomyślnie rektorem Uniwersytetu Poznańskiego (Labuda 1969, s. 9). 
doktorska Janiny Klawe, której promotorem był Florian Znaniecki, natomiast Jan Stanisław Bystroń został jej recenzentem (Znamierowska-Prüfferowa 1976, s. 376). Praca zatytułowana Totemizm a pierwotne zjawiska religijne w Polsce (Klawe 1920) była pierwszym doktoratem etnologicznym obronionym na Uniwersytecie Poznańskim.

Ponadto w trakcie pobytu w Poznaniu etnolog utrzymywał ożywione kontakty zagraniczne. Jako delegat Senatu i Uniwersytetu Poznańskiego uczestniczył w Zjeździe Historyków Religii w Paryżu (1923) oraz Międzynarodowym Kongresie Geografów w Kairze (1925). Udzielał się także w towarzystwach i komisjach naukowych, takich jak Towarzystwo Przyjaciół Nauk w Poznaniu i Komisji Antropologicznej Akademii Umiejętności w Krakowie. Jego kariera naukowa rozwijała się bardzo dynamicznie, a jej ugruntowaniem była nominacja z 31 maja 1922 roku na profesora zwyczajnego etnologii.

Bystroń duże znaczenie przypisywał refleksji nad znaczeniem i statusem nauk etnologicznych, jak również zabierał głos w ogólnych dyskusjach na temat potrzeb krajowej nauki. Po zakończeniu I wojny światowej wśród badaczy szczególnie istotne było poczucie realizacji nowych zadań stawianych przed nauką, $\mathrm{w}$ tym również przed etnologią. Wynikały one z potrzeb państwa i tworzącego je społeczeństwa, z których najważniejszymi były zespolenie dotąd rozdzielonych zaborami dzielnic, integracja narodowa oraz rozpoznanie trudności związanych ze współżyciem w tym państwie odrębnych grup narodowych i etnicznych (Jasiewicz 2018, s. 61). Usytuowanie etnologii w strukturach uniwersyteckich i tworzenie dla niej form organizacyjno-instytucjonalnych wymagało zatem głębszej refleksji naukoznawczej. W tekście zatytułowanym Ludoznawstwo na prowincji Bystroń (1923a) zwrócił uwagę nie tylko na bieżące zagadnienia $\mathrm{w}$ obrębie dyscyplin, ale także sformułował kilka pytań dotyczących krytyki zasobów naukowych i praktycznych możliwości wykorzystania wiedzy kulturowej, szczególnie na gruncie muzealnictwa wspierającego idee dziedzictwa narodowego. Znamienne było to, że tekst ukazał się w pierwszym czasopiśmie poświęconym nauce - „Nauka Polska, Jej Potrzeby, Organizacja i Rozwój”, które w okresie międzywojennym uformowało podstawy teoretyczne polskiego naukoznawstwa (Wrona 2004, s. 21). Paradoksalnie powyższy artykuł nie odnosił się wyłącznie do ludoznawstwa, ale stanowił próbę szerszego spojrzenia na etnologię jako naukę syntetyczną, która nie była kolażem intelektualnych gatunków, ale raczej otwartym na otoczenie projektem opisywania różnorodnych sposobów myślenia o świecie.

Etnologia „syntetyczna” - zdaniem Bystronia - polegałaby na systematyzacji materiału etnograficznego, w ścisłym związku z całym „ruchem naukowym w kraju i zagranicą" (Bystroń 1923a, s. 191), a przede wszystkim na świadomej współpracy z historykami, filologami, prehistorykami i antropologami. Konkretyzując charakter dyscypliny w późniejszej książce Wstęp do ludoznawstwa polskiego, którą wydał, będąc już profesorem Uniwersytetu Jagiellońskiego, sprowadził „syntetyczność” etnologii do poziomu refleksji socjologicznej. Tak rozumiana etnologia interesuje się cały czas zespołami kultur i rekonstrukcją ich dziejów, wciąż zbliża się do nauk historycznych, ale jednocześnie podąża $\mathrm{w}$ kierunku nauk społecznych, przede wszystkim socjologii, uzyskując tym samym charakter nauki bardziej teoretycznej i ogólnej (Bystroń 
1926, s. 8). Należy przy tej okazji zaznaczyć, że wspomniany Wstęp do ludoznawstwa polskiego był pokłosiem prowadzonych przez Bystronia wykładów na Uniwersytecie Poznańskim. W przedmowie autorskiej napisał on:

„Wstęp do ludoznawstwa” wykładałem w trymestrze jesiennym w r. 1924/5 w uniwersytecie poznańskim, w trymestrze jesiennym w r. 1925/6 w uniwersytecie Jagiellońskim. Z notatek powstała książka, której wad i niedociągnięć jestem dobrze świadom. Uważam jednak, że w dzisiejszym stanie ludoznawstwa, w okresie dezorientacji co do jego metod i rozproszkowania badań szczegółowych pożyteczną jest każda praca, chociażby bardzo niedoskonała, która stara się ująć jakąś obszerniejszą całość. Uważam także, że trzeba mieć odwagę ogłosić drukiem to, co miało się odwagę wykładać z katedry uniwersyteckiej (Bystroń 1926, brak nr stron).

Książka była więc nie tylko podręcznikiem wiedzy o ludoznawstwie, ale też stanowiła ślad dokonań dydaktycznych Bystronia. Współcześnie pozostaje żywym dowodem tego, co mówił i przekazywał studentom w trakcie swoich wykładów, konwersatoriów, spotkań. Można powiedzieć, że stanowi rodzaj dydaktycznego świadectwa, które zdradza nam charakterystyczne trajektorie myślenia o przedmiocie badań i odkrywa dylematy poznawcze samego autora. W pewnym sensie Bystroń był świadomy, że wydanie wykładów w formie książkowej nie było arcydziełem sztuki etnologicznej. Jednakże uważał, że pomimo różnych wad było przedsięwzięciem potrzebnym, nierzadko pozwalającym otworzyć nowe ścieżki myślenia ku temu, aby fragmentaryczną formę wykładów zastąpić bardziej wyczerpującym wywodem naukowym.

Dla Bystronia etnologia była również nauką inkluzywną, łączącą odmienne perspektywy poznawcze, a także - co może też i dzisiaj budzić niemałe kontrowersje - nauką dla każdego. Napisał on: „Każdy może zostać etnografem, [...] jeśli ma oczy otwarte na swe otoczenie, umie trafnie rzecz ująć i wiernie zapisać" (Bystroń 1923a, s. 192). Taka perspektywa, sygnowana hasłami niemal nieograniczonych „możliwości czynienia obserwacji ludoznawczych” (tamże, s. 196) wraz z szeroko zdefiniowanym polem badawczym etnologii i jej umiejscowieniem wśród innych nauk, wyraźnie odchodziła od dominującego w tamtym czasie myślenia o etnologii jako nauce historycznej.

Już we wczesnych tekstach Bystronia odnajdujemy pewne problemy, które dopiero po latach staną się istotne nie tylko dla samej etnologii, ale także całej humanistyki. Można odnieść wrażenie, że istnieje wiele podobieństw nakreślonego przez Bystronia przedmiotu etnologii do jej bardziej współczesnych odmian teoretycznych i metodologicznych. Chodzi tutaj o kwestie, które obecne są choćby w takich tematach jak „płynna nowoczesność”, „wyobraźnia etnograficzna”, „rozmycie granic dyscyplinarnych" czy „świadomość udziału w pewnej wspólnocie tworzenia faktów i ich interpretacji”. Dobrze oddaje to fragment Wstępu do ludoznawstwa polskiego: „Nie przywiązujmy znaczenia do ścisłego przestrzegania granic, których nie można dokładnie określić, ani do sporów o kompetencje w tym zakresie" (Bystroń 1926, s. 11). Ten krótki cytat można uznać za bystroniowskie credo przyświecające definiowaniu i konceptualizacji etnologii, której przypisać trzeba pluralizm teorii i metod czy wreszcie - tak wyraźnie artykułowane przez autora - dowartościowanie rozmytych sfer nauki i kultury. 
Powróćmy jeszcze na chwilę do artykułu Ludoznawstwo na prowincji. Odnajdziemy w nim również bardziej alarmistyczny ton wypowiedzi. Polska etnologia okresu międzywojennego borykała się bowiem z mnóstwem problemów. Jak napisał Bystroń, dla etnologa „pracy jest dość” (Bystroń 1923a, s. 190). Krytyka dotyczyła wielu sfer życia instytucjonalnego oraz działań, które podejmuje etnograf. Wielką rolę przypisywał chociażby muzeom etnograficznym, które znajdowały się „w smutnym stanie" (tamże, s. 191). Wojna zniszczyła większość zbiorów i zahamowała rozwój placówek muzealnych. Bystroń postulował, aby odbudowywane muzea stołeczne, a także regionalne pełniły znaczącą funkcję naukową poprzez aktywne uczestnictwo w kształtowaniu rodzimego ruchu intelektualnego.

Był on także świadomy, że bezwzględnym warunkiem rozwoju studiów etnograficznych są czasopisma naukowe. Na początku lat 20. XX wieku w Polsce ukazywały się dwa czasopisma etnograficzne - „Wisła” i „Lud”, których wydawanie mocno komplikowały trudne powojenne warunki ekonomiczne. Etnolog narzekał na poziom merytoryczny „Wisły” w odróżnieniu od „Ludu”, we wznowieniu którego widział najpilniejszą potrzebę (tamże, s. 198). Między innymi jego staraniami ukazał się pierwszy tom „Ludu” w serii drugiej w 1922 roku. Redaktorem naczelnym czasopisma został Adam Fischer, a Bystroń obok Wilhelma Bruchnalskiego, Adolfa Chybińskiego, Jana Czekanowskiego, Eugeniusza Frankowskiego, Andrzeja Gawrońskiego i Leona Kozłowskiego współtworzył pierwszy komitet redakcyjny. Oczywiście sam opublikował w nim kilka artykułów, jak Okręcanie się obrzędowe (Bystroń 1922b) oraz Czarność obcych (Bystron 1922a). W trakcie pobytu w Poznaniu Bystroń regularnie publikował na łamach „Ludu” swoje rozprawy, a także zamieszczał recenzje, materiały i notatki etnograficzne. Później jego aktywność wydawnicza w „Ludzie” znacznie zmalała.

\section{OBSZARY I KIERUNKI BADAŃ}

Badacze myśli społecznej Jana Stanisława Bystronia wskazują, że jednym z najważniejszych obszarów jego etnologicznej eksploracji była kultura ludowa (np. Sierakowski 2008, s. 163). Należy dodać, że tematyka ta zajmowała poczesne miejsce nie tylko w jego studiach. Wśród etnologów okresu międzywojennego dominował pogląd, że wielowiekowa kultura ludu była największą ostoją polskości (por. Fischer 1926, s. IV; Frankowski 1923, s. 217), a przywracanie bytu państwowego sprzyjało podejmowaniu pogłębionych badań wśród warstw chłopskich. Główną dziedziną ówczesnych zainteresowań Bystronia była pieśń ludowa. Już w 1920 roku napisał i rok później wydał pierwszą książkę poświęconą temu zagadnieniu. Artyzm pieśni ludowej (Bystroń 1921a) to publikacja, w której udało mu się zebrać ogromny materiał z zakresu polskiej poezji ludowej i jak na owe czasy dokonać bardzo nowatorskiej analizy. Jak wskazywał sam tytuł książki, interesował go przede wszystkim estetyczny wymiar ludowej literatury. Pomimo iż posługiwał się przykładami z terenów Polski, to jego zamierzeniem było badanie pieśni ludowej w ogóle, ambicją zaś próby pro- 
wadzenia bardziej ogólnych analiz etnologicznych. Książka podzielona została na dwie części: pierwsza dotyczyła istoty pieśni ludowej, to znaczy problemów definicyjnych, jej podstawowych cech, zmienności czy charakteru treści, druga natomiast artyzmu pieśni ludowej, w szczególności jej konstrukcji, opisów zawartych w tekstach, typizacji, stylu oraz ludowego światopoglądu. Wszystkie te elementy traktował jako integralne składowe pieśni ludowej.

Bystroń nie tylko doceniał oryginalność poezji ludowej, ale także usiłował ją dowartościować i zarazem nobilitować do rangi pełnoprawnej literatury. Charakteryzując artyzm utworów ludowych, napisał między innymi:

Z chwilą, gdy zmieniły się nasze pojęcia o świecie, w pierwszym rzędzie o przyrodzie, świat pieśni, coraz dalszy od rzeczywistych stosunków, wydawał się coraz piękniejszym. Mówił Goethe, że to co ma żyć w pieśni, musi zaginąć w życiu; głęboką tę myśl możnaby zastosować także i do naszego przypadku (Bystroń 1921a, s. 161).

Bezimienna twórczość ludu miała więc w sobie znaczącą wartość estetyczną, która odsłaniała ludową wizję świata i nadrzędne systemy wartości. Poezja ludowa jako emanacja kultury ludowej interesowała go w procesie zmiany, stąd udało mu się wyeksponować nie tylko różnorodność samej twórczości ludzi żyjących na polskiej wsi, ale też uchwycić jej dynamizm i zmienność historyczną.

Artyzm pieśni ludowej po ukazaniu się drukiem nie został przyjęty entuzjastycznie w środowiskach akademickich. Choć niewątpliwie krytycy książki zauważali jej unikatowy charakter i nie odmawiali zainteresowania książką, to zarzucali Bystroniowi lekceważenie dorobku innych badaczy, przede wszystkim zagranicznych, pisanie w stylu popularnonaukowym, a nie naukowym, redukcjonistyczne podejście, niejasne porównania do poezji współczesnej i literatury, wątpliwości co do kulturowych analiz estetycznego wymiaru pieśni ludowej, a także kategorii formułowanych rozważań. Narracja książki wydawała się niezrozumiała dla przedstawicieli innych nauk niż etnologia, a bystroniowski wywód nazbyt odbiegający od ówczesnych standardów pisarstwa akademickiego. Jeden z krytyków napisał:

Pierwsza polska książka, która się zajmuje poezją ludową, wyszła też nie z pod pióra filologa-poloni-
sty, lecz z pod pióra etnologa. Już to samo określa poniekąd charakter tej książki. Bo choć autorowi
nie brak jest subtelnego wyczucia estetycznego, punkt widzenia etnologa jest przecież inny niż
filologa. [...] Stanowisko krytyka wobec książki p. Bystronia jest dość kłopotliwe, a w sytuację tę
wprawia krytyka autor sam, przez to, że nie dość dokładnie orjentuje czytelnika o rodzaju i istocie
swego zamierzenia (Łempicki 1921/1922, s. 155).

Ponadto Artyzm pieśni ludowej został wydany w atmosferze pewnego skandalu. Drukarnia i Księgarnia Św. Wojciecha zarzuciła Bystroniowi, że nie uprzedził o równoczesnym zamiarze wydania, jak napisali „prac nieomal identycznych, a w każdym razie tak bardzo zbliżonych tematem, układem, tytułami rozdziałów" (List do dra Jana Bystronia z dnia 30 grudnia 1920 r.). Zdaniem przedstawicieli Drukarni i Księgarni Św. Wojciecha wydawany przez nich Artyzm pieśni ludowej był niemal identyczny z oddaną do druku w Krakowskiej Spółce Wydawniczej Polską pieśnią ludową. Wybór (Bystron 1921b). Bystroń nie zgadzał się z pretensjami firmy 
wydawniczej, a całą sprawę nagłośnił wśród profesorów Uniwersytetu Poznańskiego, kierując ją do zbadania przez Senat uczelni. Niezależne orzeczenie napisał Stanisław Dobrzycki, uznany historyk literatury i późniejszy rektor Uniwersytetu Poznańskiego. Stwierdził on między innymi, że

Polska pieśń ludowa. Wybór jest antologią, wyborem z zasobów pieśni ludowej, jest zbiorem tekstów. Artyzm pieśni ludowej jest pracą ściśle naukową konstruktywną, jest rozprawą, omawiającą jedną z właściwości pieśni ludowej. Książka pierwsza podaje materiał, druga jest opracowaniem i wyjaśnieniem pewnego zagadnienia naukowego, łączącego się z poezją ludową. Są to więc dwie rzeczy zupełnie różne. Twierdzenie o ich nieomal identyczności polegać musi na jakimś nieporozumieniu, może na nieznajomości jednej z nich. Żądanie, aby autor uprzedzał wydawcę jednej swojej książki, o równoczesnem wydaniu innej pracy (książki) gdzieindziej, nie ma najmniejszego uzasadnienia, ani w ustawodawstwie o własności literackiej, ani w zwyczajach, ani w etyce (Orzeczenie Stanisława Dobrzyckiego z dnia 30 stycznia 1921 r.).

Również Senat Uniwersytetu Poznańskiego kilka miesięcy później wydał oświadczenie, że postępowanie Bystronia było zupełnie poprawne, a o jakiejkolwiek jego nielojalności naukowej lub wydawniczej nie może być mowy (Dokument Uchwały Senatu Uniwersytetu Poznańskiego z dnia 11 sierpnia 1921 r.). W efekcie Drukarnia i Księgarnia Św. Wojciecha przyjęła wyjaśnienia i cofnęła „gorzkie słowa wypowiedziane w liście do prof. Bystronia" (List Drukarni i Księgarni Św. Wojciecha z dnia 1 marca 1921 r.).

Dla Bystronia zainteresowania pieśnią ludową sprawiały wrażenie ogólnego przedmiotu badań etnologicznych. Oznaczało to, że analizy naukowe powinny wydobywać na światło dzienne nowe problemy i zagadnienia społeczne. Klasyczne tematy związane $\mathrm{z}$ kulturą ludową wymagały twórczego przepracowania i uaktualnienia. Taki zamysł teoretyczny przyświecał nie tylko Artyzmowi pieśni ludowej i Polskiej pieśni ludowej. Wybór, lecz także stanowił punkt wyjścia dla artykułów takich jak Pieśn o dziewczynce i przewoźniku (Bystroń 1923b,) czy Wpływy pieśni szlacheckich $w$ poezji ludowej (Bystroń 1924b). Obok wymienionych książek i artykułów, jeszcze będąc kierownikiem Katedry Etnologii w Poznaniu, napisał kolejną monografię z tego zakresu pod tytułem Historja w pieśni ludu polskiego (Bystroń 1925). Na podstawie starannie dobranego materiału etnograficznego dokonał analizy tych pieśni ludowych, w których zawarte były motywy historyczne. Wydarzenia sprzed wieków $\mathrm{i}$ lat, których echa pobrzmiewały w folklorze ustnym, uporządkował zgodnie z rzeczywistą chronologią dziejów narodu polskiego: od wspomnień o potopie szwedzkim z 1655 roku po powstanie styczniowe z 1863 roku i walkach w służbie austriackiej wraz z okupacją Bośni w 1878 roku. Nie zajmowały go już kwestie estetyki pieśni ludowych, ale zagadnienia świadomościowe i wyobrażenia dotyczące faktów historycznych. Odpowiednio wyselekcjonowane pieśni ludowe z zawartymi treściami historycznymi ułożyły się w niezwykle specyficzną narrację etnograficzną. Była to bowiem ludowa historia Polski - historia zapamiętana i opowiedziana przez ludność wsi, włościan, rekrutów i wędrownych żebraków.

Świadomość historyczna była dla Bystronia niczym innym jak kompleksem kulturowych wyobrażeń o przeszłości. W pieśniach ludowych, jak napisał: 
Idealizuje się własnych bohaterów, przedstawia się ich w najkorzystniejszym świetle, na odwrót zaś wrogów wyobraża się zawsze jako okrutników i bezbożników. Następnie wypadki się ubarwia, przedstawia się je w pełniejszym świetle, normalnie wplata się tutaj jakieś elementy ponadnaturalne, aby opisywanym zdarzeniom dodać poezji i prozy; Bóg jest po stronie walczących za dobrą sprawę, pomaga im w boju i dzieją się w czasie bitwy cuda, które powodują wreszcie klęskę bezbożnych (Bystroń 1925, s. 8).

Bystroń podkreślał niezwykle istotną rolę, jaką odegrała pieśń w kształtowaniu świadomości narodowej warstwy chłopskiej. Z niej mieszkańcy wsi dowiadywali się o tradycjach narodowych i religijnych. Zmitologizowana historia pielęgnowana w ludowej twórczości była swoistym wstępem do późniejszej rozprawy Megalomania narodowa (Bystroń 1935), której pierwsza wersja ukazała się na łamach „Przeglądu Społecznego" już w lutym 1924 roku.

W tekście zamieszczonym w „Przeglądzie”, a później w książce o megalomanii narodowej, Bystroń pisał o formach idealizowania własnej grupy etnicznej. Megalomania narodowa była elementem wiary, mitem własnego etnosu jako grupy wybranej, przeświadczonej o swojej najwyższej wartości, roszczącej sobie prawo "górowania” nad obszarem rozciągającym się dookoła niej (Bystroń 1935, s. 12). Ten sposób myślenia „o sobie i innych" uruchamiał poglądy o najdoskonalszym w świecie ustroju społecznym panującym w Polsce, dziejowej - niemal boskiej - misji, jaką było wyobrażenie polskości w kategoriach przedmurza chrześcijaństwa i obrony przed islamem, a także popularyzacji romantycznej idei Polski jako Chrystusa Narodów, które trwale zmityzowały świadomość narodową wielu pokoleń Polaków.

Koncepcja megalomanii narodowej musiała odbić się szerokim echem nie tylko w środowisku naukowym, ale również w społeczeństwie, które zaledwie od kilku lat mogło cieszyć się niezawisłością państwową. Według krytyków - szczególnie tych związanych z endecją i środowiskami narodowymi międzywojennej Polski - etnologiczne studium poświęcone „zarozumiałości plemiennej” rozbijało poczucie jedności duchowej narodu. Zygmunt Wasilewski napisał w „Przeglądzie Wszechpolskim”: "Cóż się stało z umysłowością polską Śniadeckich, Stasziców, Kołłątajów, Ochorowiczów, Świętochowskich, że doszło do p. Bystronia!” (Wasilewski 1924, s. 860). Zarzucał Bystroniowi między innymi to, że „wybił Polakom z głowy i serca miłość do ojczyzny i narodu" (tamże, s. 861). Jego zdaniem postawa poznańskiego profesora była reakcją „chorej umysłowości polskiej z czasów niewoli” (tamże, s. 863). Megalomania narodowa odebrana została jako przykład upadku dwudziestowiecznych idei suwerenności i obskurantyzmu krzewionego przez wartości antynacjonalistyczne. Wasilewski nie szczędził ostrych słów i nie krył wzburzenia:

Prof. Bystroń wykłada podobno etnologię na uniwersytecie poznańskim, ma przeto przy swojej pracowitości możliwość gruntownego zajęcia się nauką o narodzie. Jest Polakiem, zna dzieje naszej cywilizacji i wie, z jakim trudem i katastrofami Polska, wśród swoich złych granic, otoczona zewsząd wrogami, czyhającymi na jej ziemię, organizowała swoją myśl cywilizacyjną. Dotąd sądziliśmy, że to było bonum necessarium i prof. Bystroń może na to się zgodzi, choćby ze względów taktycznych, że dobrze się stało, iż plemię słowiańskie potrafiło się obronić od zagłady i więcej: potrafiło stworzyć swoją indywidualność cywilizacyjną (Wasilewski 1924, s. 860). 
Nie można się dziwić, że koncept megalomanii narodowej wśród środowisk prawicowych odebrany został z dużą niechęcią. Etnologiczne studium nad etnocentryzmem i procesami idealizacji własnej kultury miało w dużej mierze charakter demaskatorski: obnażało słabości narodowych mitów i podważało „odwieczne i święte” prawdy o samych Polakach. Poglądy Bystronia dotyczące chociażby szkodliwości stereotypów etnicznych czy zagrożeń wynikających z poczucia wyższości własnej grupy narodowej nad innymi kontrastowały $\mathrm{z}$ popularnymi $\mathrm{w}$ dwudziestoleciu międzywojennym ideologiami narodowościowymi. Megalomania narodowa wytrzymała próbę czasu i napór krytyki, pretendując do jednego z wybitniejszych dzieł polskiej humanistyki.

Nie będzie przesady w stwierdzeniu, że dla Jana Stanisława Bystronia etnologia była dziedziną, która przekraczała wszelkie bariery pomiędzy naukami. Zakres jego zainteresowań, inteligencja i ogrom erudycji przełamywały sztywne granice dyscyplin (Bielak 1979, s.286). Widać to doskonale w przenikaniu się badań nad literaturą ludową i piękną. Jeszcze w 1922 roku Bystroń wydał obszerny esej Wyobraźnia artystyczna Bolesława Prusa (1922c). Zajmowały go przede wszystkim motywy obrazowania, a także sposoby posługiwania się barwami i światłem w jego twórczości. Z pewnością esej nie był klasyczną pozycją etnograficzną - „terenem” była tutaj literatura, a narzędziami metody lingwistyczne. Bystroń wykazywał, że dla Bolesława Prusa ważna była otaczająca rzeczywistość, którą uważnie obserwował, a następnie jako pisarz twórczo przekształcał w fabułach swoich dzieł. Jego zdaniem Prus nie zwracał uwagi na wrażenia sensoryczne, lecz przekazywał wiadomości o stosunku człowieka do opisywanej przyrody, miejsc lub rzeczy. Paradoksalnie skala barw u Prusa była bardzo uboga, a sam pisarz zachowywał się i patrzył na świat podobnie jak naukowiec - najpierw prowadził pogłębione studia nad podjętymi problemami, a następnie zajmował się ich literackim przedstawieniem.

Dla Bystronia punktem wyjścia w myśleniu o literaturze pozostawała więc etnologia ze swoim zmysłem zrozumienia człowieka i wszelkich przejawów życia społecznego $^{2}$. Jego interpretacja prozy polskiego pozytywisty była tak samo wielokontekstowa, jak wielopoziomowa. Wśród szeregu literackich opisów dostrzeżonych i wyróżnionych przez Bystronia na uwagę zasługują te, które dotyczyły miast. Prus obserwował między innymi zmiany, jakie niósł ze sobą dziewiętnastowieczny kapitalizm, dokładnie przyglądał się miejskim topografiom i architekturze. Być może właśnie te realistyczne opisy będące częścią utworów literackich sprawiły, że Bystroń zainteresował się bliżej kwestiami miejskimi.

Już w 1923 roku w czasopiśmie „Ziemia” zamieścił krótki artykuł dotyczący rozwoju Krakowa. Rozrost wielkich miast pod koniec XIX wieku i w pierwszej połowie $\mathrm{XX}$ wieku następował bardzo szybko. Bystroń starał się dostrzec mechanizmy, które

${ }^{2}$ Warto w tym miejscu wspomnieć, że Bystroń omawiał także twórczość innych pisarzy i poetów, na przykład Juliana Tuwima czy Stanisława Przybyszewskiego. Przykładem może być recenzja: Julian Tuwim, Czary i czarty polskie oraz wypisy czarodziejskie - Stanisław Przybyszewski Il regno doloroso (Bystroń 1924a). 
sprzyjały tworzeniu wielkich ośrodków miejskich. Wskazywał głównie na migracje ze wsi do miast, dynamiczny rozwój przemysłu i coraz doskonalszą sieć komunikacyjną, które stymulowały procesy miastotwórcze. Badając wielkomiejski charakter Krakowa, korzystał z różnych źródeł - spisów ludności, danych historycznych, rycin, map. $\mathrm{Na}$ ówczesne czasy była to analiza bardzo nowoczesna, zogniskowana na problemie funkcjonalności miasta jako całości. Zagadnienie wielkomiejskości interesowało go w kontekście spójności przestrzennej. O Krakowie pisał, że jest zbudowany „koncentrycznie, rozwija się wzdłuż promieni najważniejszych dośrodkowych dróg, łączących środek miasta z gminami podmiejskimi, a dalej z innymi centrami” (Bystroń 1923c, s. 158). Rozwój miast polskich w latach 20. XX wieku wiązał się ze zmianami ludnościowymi, urbanizacyjnymi i infrastrukturalnymi. Bystroń nie tylko zauważał te procesy, ale też usiłował je syntetyzować, wskazując chociażby na wypieranie z centrów miast dotychczasowych mieszkańców i przekształcanie śródmieść w dzielnice handlowe, tworzenie enklaw dla ubogiej i zamożnej ludności miasta, pauperyzację części mieszczan. Ten niewielkich rozmiarów artykuł poświęcony Krakowowi można dziś uznać za zwiastun antropologii miasta w Polsce. W ślad za nim Bystroń opublikował później drobne teksty na temat napisów w przestrzeni miejskiej (np. Bystroń 1927), a po II wojnie światowej wydał książkę o dziejach Warszawy (Bystroń 1949).

\section{ZAKOŃCZENIE}

Zaledwie paroletni okres instytucjonalnego związku Bystronia z Poznaniem wiązał się z intensywną działalnością naukową, która skupiła się na kierowaniu nowo powstałą Katedrą Etnologii Uniwersytetu Poznańskiego, a także dydaktyce i aktywności wydawniczej. Bystroń był tym, od którego rozpoczęła się historia uniwersyteckiego ośrodka etnologicznego w Poznaniu. To głównie dzięki jego osobie udało się stworzyć instytucyjne podstawy dla funkcjonowania tej dyscypliny i zyskać grono studentów zainteresowanych wiedzą o kulturze. System uniwersyteckiego kształcenia etnologów przez pierwsze lata funkcjonowania katedry pozostawał na jego barkach. Bez wątpienia Bystroń wywiązywał się ze wszystkich swoich obowiązków, które wynikały z kierowania katedrą. Mimo tego nigdy nie związał się bliżej z Poznaniem. Nie miał tutaj mieszkania i brał urlopy, kiedy tylko mógł. Ciągnęło go do Krakowa, w którym się wychował i z którym nie zerwał kontaktów nawet po przyjeździe do Poznania. W roku akademickim 1920/1921 otrzymał urlop, a w spisach wykładów z tych lat pojawiła się lapidarna informacja, że „Prof. Bystroń w bieżącym roku wykładać nie będzie" (Uniwersytet Poznański, Spis wykładów 1920/1921). Profesor otrzymał również urlop w roku akademickim 1923/1924 i chciał go przedłużyć na następny rok, jednak Rada Wydziału Filozoficznego na posiedzeniu 31 marca 1924 roku oraz Senat Akademicki Uniwersytetu Poznańskiego nie zgodziły się, a Ministerstwo Wyznań Religijnych i Oświecenia Publicznego poinformowało, że „przedłużenie urlopu Prof. Dr. Bystronia celem prowadzenia wykładów w Uniwersytecie Jagiellońskim, ze 
względu na wynikające stąd szkody dla Uniwersytetu Poznańskiego nie jest możliwe" (Pismo Ministerstwa Wyznań Religijnych i Oświecenia Publicznego z dn. 6 maja 1924 r.). Również konflikt z Drukarnią i Księgarnią Św. Wojciecha w Poznaniu dotyczący wydania Artyzmu pieśni ludowej nie wpływał pozytywnie na dłuższe pozostanie w Wielkopolsce. Już 11 września 1925 roku Prezydent Rzeczypospolitej mianował Bystronia profesorem zwyczajnym etnologii i etnografii w Uniwersytecie Jagiellońskim i poprosił o zwolnienie go z dotychczasowych obowiązków, dla objęcia nowego stanowiska (Pismo Ministerstwa Wyznań Religijnych i Oświecenia Publicznego z dn. 30 września 1925 r.). Tym samym Bystroń powrócił do Krakowa.

Pomimo różnych trudności Jan Stanisław Bystroń bardzo dużo publikował. W okresie 1919-1925 wydał kilka monografii autorskich i szereg artykułów w różnych czasopismach - takich jak „Lud”, „Przegląd Współczesny”, „Nauka Polska”, "Przegląd Warszawski”, „Ziemia”, „Orli Lot”. Ważnym przedmiotem badań pozostawała dla niego kultura ludowa, ale w swoich studiach znacząco wykraczał poza jej zakres. Cały czas poszukiwał nowych tematów i odkrywał nowe zjawiska kulturowe, nie ograniczał się wyłącznie do analiz jednej warstwy społecznej. Oprócz klasy chłopskiej interesował się mieszczaństwem i obyczajami szlacheckimi, ciekawiła go kultura codzienności i kultura miejska. Takie ujęcie kultury dało początek koncepcji „kultury typu ludowego", którą swojego czasu rozwinął Ludwik Stomma. Dla Bystronia etnologia była dziedziną „bez barier”, przenikającą do innych nauk i jednocześnie zaangażowaną w ważne sprawy społeczne. Badania kultury ludowej miały swoje uzasadnienie w koncepcjach narodu, a megalomania narodowa stanowiła rodzaj diagnozy społeczeństwa polskiego zaraz po odzyskaniu niepodległości. Oczywiście wiele spostrzeżeń Bystronia ma dziś walor wyłącznie historyczny, ale wiele z nich wciąż zaskakuje swoją aktualnością i niesłabnącą popularnością.

Życie i praca naukowa Bystronia przypadły na niespokojne czasy: okres zaborów, dwie wojny światowe, walka o niepodległość i okres komunizmu w Polsce. Szczyt jego naukowych możliwości nastąpił w epoce dwudziestolecia międzywojennego, która nie tylko zapewniła suwerenność narodowi polskiemu, ale też dawała wolność formułowania naukowych myśli. Dla wielu ludzi nie była to jednak epoka łatwa do życia, a zarazem do uprawiania nauki. Problemów przysparzała odbudowa szkolnictwa wyższego, organizacja uniwersytetów, ujednolicenie systemu studiów, rozwój bazy dydaktycznej, kompletowanie kadry naukowej, tworzenie nowych ośrodków badań i zapewnienie finansowania nauki (Czech-Jezierska 2011, s. 161). W programowym tekście Ludoznawstwo na prowincji Bystroń pisał o trudnościach, z którymi borykały się nauki etnologiczne. Były to między innymi: brak kadr, niedofinansowanie badań, zbyt mała liczba czasopism etnologicznych, niedobór odpowiedniej literatury do prowadzenia zajęć uniwersyteckich ze studentami. Mimo tego etnologia zajmowała ważne miejsce wśród innych nauk. Pokazywała to sytuacja w Poznaniu. Katedra Etnologii była integralną częścią Wydziału Filozoficznego i Uniwersytetu Poznańskiego od momentu ich powołania. Mogło się tak właśnie stać, gdyż dyscyplina ta miała status samodzielnej nauki, której nikt wówczas nie kwestionował. Czy można porównać ówczesną sytuację ze współczesną? 
Historia nigdy nie jest procesem następujących po sobie linearnie zdarzeń i faktów nawet wtedy, gdy zachodzą one w mikroskali. Etnologia pierwszej połowy XX wieku funkcjonowała w świecie dużych społecznych kryzysów. Również współczesne kryzysy nabierają nowych znaczeń w zmieniających się kontekstach społecznych i politycznych. Ulrich Beck (2002) napisał, że żyjemy w świecie ryzyka, które ma wymiar uniwersalny. Dziś bez wątpienia kryzys dławi polską etnologię, ale ma szczególny wymiar i źródło. Reforma szkolnictwa wyższego wdrażana w ostatnim czasie wymazała ją z obszaru dyscyplin naukowych ${ }^{3}$. Parafrazując tytuł artykułu Bystronia Ludoznawstwo na prowincji, można powiedzieć, że dziś „na prowincji” nauk znalazła się sama etnologia. Z dyscypliny, która jeszcze niedawno przebojem dokonywała „antropologizacji innych dyskursów”, stała się dziedziną wiedzy „wykreśloną” z urzędniczych wykazów, „schowaną” w ogólnym zbiorze nauk o kulturze i religii. Debaty wokół statusu etnologii jeszcze bardziej zyskały na znaczeniu. Być może konieczność przezwyciężenia tego niekorzystnego stanu będzie najważniejszym wyzwaniem, przed którym właśnie stanęliśmy.

\section{LITERATURA}

B e ck U lri ch 2002, Społeczeństwo ryzyka. W drodze do innej nowoczesności, tłum. S. Cieśla, Scholar, Warszawa.

Bielak Franciszek 1965, Jan Stanisław Bystroń (20 października 1892 - 18 listopada 1964) [nekrolog], Pamiętnik Literacki, nr 56 (3), s. 301-303.

Bielak Franciszek 1979, Z odległości lat. Wspomnienia i sylwetki, Wydawnictwo Literackie, Kraków.

Bystroń Jan Stanisław 1914, Teoria rzeczywistości społecznej (praca doktorska), Kraków.

B y st r oń Jan St a n i sła w 1916, Zwyczaje żniwiarskie w Polsce, Akademia Umiejętności, Kraków. Byst roń Ja n St a n isła w 1921a, Artyzm pieśni ludowej, nakład Księgarni św. Wojciecha, Poznań-Warszawa.

Bystroń Jan Stan isław 1921b, Polska pieśń ludowa. Wybór, Krakowska Spółka Wydawnicza, Kraków.

Bystroń Jan Stanisław 1922a, Czarność obcych, Lud, seria II, t. 1, s. 179-182.

Bystroń Jan Stan isław 1922b, Okręcanie się obrzędowe, Lud, seria II, t. 1, s. 93-96.

Bystroń Jan Stanisław 1922c, Wyobraźnia artystyczna Bolesława Prusa, Przegląd Warszawski, nr 11, s. 151-191.

Bystroń Jan Stan isław 1923a, Ludoznawstwo na prowincji, Nauka Polska, Jej Potrzeby, Organizacja i Rozwój, t. 4, s. 190-203.

Bystroń Jan Stan isław 1923b, Pieśń o dziewczynce i przewoźniku, Lud, seria II, t. 2, s. 63-71. Bystroń Jan Stan isław 1923c, Rozwój wielkomiejski Krakowa, Ziemia, nr 6-8, s. 157-160.

Bystroń Jan Stan isław 1924a, Julian Tuwim, Czary i czarty polskie oraz wypisy czarodziejskie - Stanisław Przybyszewski Il regno doloroso, Przegląd Wspótczesny, nr 29, s. 473-477.

Bystroń Jan Stan isław 1924b, Wpływy pieśni szlacheckich w poezji ludowej, Lud, seria II, t. 3 , s. $112-126$.

${ }^{3}$ Więcej na temat reformy szkolnictwa wyższego w Polsce oraz likwidacji etnologii i antropologii kulturowej jako samodzielnej dyscypliny można przeczytać w artykule Elżbiety M. Goździak i Izabelli Main Erasing Polish Anthropology? (2018). 
Bystroń Jan Stanisław 1925, Historja w pieśni ludu polskiego, Gebethner i Wolff, Warszawa-Kraków-Lublin-Łódź-Poznań-Wilno-Zakopane.

Byst r oń Jan St a n isław 1926, Wstęp do ludoznawstwa polskiego, K.S. Jakubowski, Lwów.

Bystroń Jan Stan isław 1927, Napisy na zewnątrz i wewnątrz domów, Ziemia, nr 12, s. 195-197.

Bystroń Jan Stanisław 1935, Megalomania narodowa, Towarzystwo Wydawnicze Rój, Warszawa.

Bystroń Jan Stan isław 1949, Warszawa, Wydawnictwo Ludwika Fiszera, Warszawa.

Bystroń Jan Stan isław 1980, Tematy, które mi odradzano. Pisma etnograficzne rozproszone, wybrał i opracował L. Stomma, PIW, Warszawa.

Cliff or d Ja me s 2000, Kłopoty z kulturą: dwudziestowieczna etnografia, literatura i sztuka, thum. E. Dżurak [et al.], Wydawnictwo KR, Warszawa.

Czech-Jezierska B ożena 2011, Okres dwudziestolecia międzywojennego a rozwój nauki prawa rzymskiego w Polsce, Zeszyty Prawnicze UKSW, nr 4, s. 161-190.

D avies Charl ot te A ull 1999, Reflexive ethnography: A guide for researching selves and others, Routledge, New York.

Dobrowolski Kazimierz, Kutrzeba-Pojnarowa Anna 1966, Sylwetka naukowa Jana Stanisława Bystronia, Etnografia Polska, t. 10, s. 15-30.

F is ch e r A d a m 1926, Lud polski. Podręcznik etnografi Polski, Wydawnictwo Zakładu Narodowego im. Ossolińskich, Lwów.

Frankowski Eugen i us z 1923, Ludoznawstwo na wsi, Nauka Polska, Jej Potrzeby, Organizacja i Rozwój, t. 4, s. 204-213.

Goździak Elżbieta, Main I zabella 2018, Erasing Polish Anthropology?, Polska Sztuka Ludowa. Konteksty, nr 4, s. 5-7.

Jakś-Ivanovska Magdalena 2016, Profesorowie Uniwersytetu Poznańskiego 1919-1939. Portret demograficzno-społeczny, Rocznik Dziejów Społecznych i Gospodarczych, t. 76, s. 341-383.

Jasiewicz Zbigniew 2018, Skąd, z czym i w jaki sposób etnografia/ etnologia/ antropologia pojawiła się przed 100 laty w odrodzonym państwie polskim?, Lud, t. 102, s. 41-83.

K la we J a n in a 1920, Totemizm a pierwotne zjawiska religijne $w$ Polsce, nakład własny, Warszawa.

L a bu d a Gerard 1969, Uniwersytet Poznański w latach 1919-1969, Kronika Miasta Poznania: kwartalnik poświęcony problematyce wspótczesnego Poznania, R. 37, nr 2, s. 5-30.

Ł e m p i ck i Zyg m u n t 1921/1922, Artyzm pieśni ludowej, Jan Stanisław Bystroń, [recenzja], Pamiętnik Literacki, t. 19, s. 154-157.

Man ce wi c z St a n isław 2001, Bystroń Jan Stanisław, Gazeta Wyborcza, 15.02.2001, wersja online: http://krakow.wyborcza.pl/krakow/1,35802,140944.html.

Robotycki Czesław 1998, Nie wszystko jest oczywiste, Wydawnictwo UJ, Kraków.

S ch r a m m To m a s z 2002, Tworzenie uniwersytetów. Kadry profesorskie uniwersytetów w Warszawie, Poznaniu i Wilnie u progu Drugiej Rzeczypospolitej, [w:] W. Mędrzecki (red.), Społeczeństwo, państwo, modernizacja. Studia ofiarowane Januszowi Żarnowskiemu w siedemdziesiąta rocznice urodzin, Instytut Historii PAN, Warszawa, s. 121-141.

S i e r a k o w s k i M a r e k 2008, Myśl społeczna Jana Stanisława Bystronia, Mazowieckie Studia Humanistyczne, nr 1-2, s. 161-179.

S uli ma Roch 2000, Antropologia codzienności, Wydawnictwo UJ, Kraków.

Tokarska-Bakir Joanna, Z awadzka Ann a 2012, Bystroń everegreen, Studia Litteraria et Historica, nr 1, s. 1-2.

Waliński Mich ał 1982, Renesans Jana Stanisława Bystronia, Regiony, nr 1-3, s. 140-146.

Wasilewski Zyg munt 1924, Rozbijanie duchowe narodu, Przegląd Wszechpolski, R. 3, listopad, s. 850-866.

Wro na Gràzyn a 2004, Nauka Polska, Jej Potrzeby, Organizacja i Rozwój (1918-1939), pierwsze polskie czasopismo naukoznawcze, Rocznik Historii Prasy Polskiej, t. 7, z. 2, s. 19-47.

Zna mierowska-Prüffer ow a Maria 1976, Janina Klawe, $L u d$, t. 60, s. 376-377. 
ADAM POMIECIŃSKI

\section{UNOBVIOUS ETHNOLOGY. IN THE FOOTSTEPS OF JAN STANISŁAW BYSTROŃ A HUNDRED YEARS LATER}

Keywords: Jan Stanisław Bystroń, ethnology of Poznań, history of ethnology in Poland.

Over a hundred years ago, Jan Stanisław Bystron became the head of the Department of Ethnology at the University of Poznan (original name Wszechnica Piastowska). He has left a huge collection of books and articles as his scientific achievements, which still inspire new generations of ethnologists and social researchers. His most intense scientific activity was during the inter-war period, in which first as a professor at the University of Poznań, and then at the Jagiellonian University and the University of Warsaw, he co-created the foundations of ethnological sciences in Poland. This article focuses on two main areas: institutional (vision of ethnology as academic science) and issues of cultural heritage. The presented text does not refer to the entire academic output of Bystroń, but above all concentrates on the years 1919-1925 - the period when he managed the Department of Ethnography in Poznań. For Bystron it was a time of intensive academic work and the beginning of formulating many research ideas that evolved later. Ethnology, in the understanding of Bystron, has made a kind of reorientation in the approach to the problems of the nation, folk, regionalism, language phenomena and history (for example Polish folk history). Many threads are also considered pioneering and sometimes controversial today. His theory of culture is also a pretext for reflection on the contemporary dilemmas of Polish ethnology, such as: the disciplinary identity, the boundaries between sciences, the role of cultural capital and knowledge transfers.

A.P.

Adres Autora:

prof. UAM dr hab. Adam Pomieciński

Instytut Etnologii i Antropologii Kulturowej UAM, Poznań

ul. Uniwersytetu Poznańskiego 7, 61-614 Poznań

E-mail: adpom@amu.edu.pl

ORCID: 0000-0002-1788-1065 